\title{
A new species of Sickesia (Laniatores: Stygnidae: Opiliones) and new records for the State of Piauí, Brazil
}

\author{
Ricardo Pinto-da-Rocha ${ }^{1} \&$ Leonardo S. Carvalho ${ }^{2}$
}

\begin{abstract}
1 Departamento de Zoologia, Universidade de São Paulo. Caixa Postal 11461, 05422-970 São Paulo, São Paulo, Brasil. E-mail: ricrocha@usp.br

2 Programa de Pós Graduação em Zoologia, Coordenação de Zoologia, Museu Paraense Emílio Goeldi, Universidade Federal do Pará. Caixa Postal 399, 66040-170 Belém, Pará, Brasil. E-mail: leosc_fla@yahoo.com.br
\end{abstract}

\begin{abstract}
Sickesia tremembe sp. nov. is described from Piauí, Northeast Brazil (type-locality: Sete Cidades National Park, Brasileira and Piracuruca municipalities). It differs from S. usta and S. helmuti by the clavate male femur IV and chelicerae segment I with a pair of large tubercles on retrolateral surface. The Stygnidae Stygnus polyacanthus (Mello-Leitão, 1923); the Cosmetidae, Gryne pluriarcuata Mello-Leitão, 1936 and undetermined species of Paecilaema and Gryne and also representatives of Escadabiidae and Sclerosomatidae (Gagrellinae) are recorded from this state, for the first time.
\end{abstract}

KEY WORDS. Cosmetidae; Escadabiidae; Neotropics; Sclerosomatidae; taxonomy.

Stygnidae comprises 85 species, restricted to the Neotropical Region, occurring in South America above the Capricorn Tropic and the Lesser Antilles (Villarreal-Manzanilla \& Pinto-DARocha 2006, Pinto-Da-Rocha 2007, Hara \& Pinto-Da-Rocha 2008, Kury \& Pinto-Da-Rocha 2008). Sickesia H. Soares, 1979, which belongs to Stygninae, has, so far, two described species: Sickesia helmuti H. Soares, 1979, known only from the type-locality (Teles Pires River, Mato Grosso State, Brazil); and S. usta (Mello-Leitão, 1941) known for Belém (Pará State, Brazil) and Santa Teresinha (Mato Grosso State, Brazil) (PINTO-DA-Rocha 1997). This genus is diagnosed by the prosoma with one spine on the anterior margin forwards and ocularium densely tuberculated (PINTO-DA-RochA 1997) and is considered sister-group of Stygnus Perty, 1833 by the following synapomorphies: dorsal scutum slightly wider at groove III, prosoma with one spine, free tergite III with a pair of tubercles longer than those of I-II and intermediary setae of ventral plate penis placed centrally (PINTO-DA-RochA 1997).

In the present paper, we describe a third species of Sickesia, and present some remarks about the harvestman fauna from the State of Piauí, Northeast Brazil, where no species have been recorded up to now (KuRY 2003). The region comprising the states of Piauí and Maranhão may contain some endemic features, as already suggested by botanical (e.g. CAstro et al. 2007) and zoological (e.g. Lourenço et al. 2006) data; because it is an ecotonal region between the humid Amazon Forest and drier opened formations, such as Cerrado (savanna-like formations from Central and Northeast Brazil) and Caatinga (dry environment with xeromorphic vegetation from Northeast Brazil) (Ducke \& Black 1953, Rizzini 1963). Despite this biological importance, the arachnid sampling and studies at Piauí are scarce, being restricted to a few records on taxonomic studies on spi- ders (e.g. Guadanucci 2007, Guadanucci et al. 2007, Ruiz \& Brescovit 2006, SANTOS \& BRESCOVIT 2001); and a few scorpion records on checklists (e.g. LOURENÇO 2002, LuCAS et al. 1979) or related envenomation cases (CARVALHO et al. 2007a); which can justify the absence of harvestman records from Piauí. Since 2003, some new collecting expeditions have been executed, providing data about the local arachnid fauna (e.g. CARvalHo et al. 2007b); and resulting on a large number of specimens caught, belonging to the orders Acari, Amblypygi, Araneae, Opiliones, Pseudoscorpiones, Scorpiones and Solifugae.

The specimens examined are deposited in the collections of Museu Paraense Emílio Goeldi (MPEG, curator: A. B. Bonaldo) and Museu de Zoologia da Universidade de São Paulo (MZSP, curator: R. Pinto-da-Rocha). All measurements are given in millimeters.

\section{TAXONOMY}

\section{Sickesia tremembe sp. nov.}

Figs 1-8

Type material. Male holotype, Piauí, Brasileira and Piracuruca, Sete Cidades National Park, F.N. Oliveira-Marques leg., 25.VI.2007, (MPEG 0042). Paratypes: 1 male, 1 female, same data as holotype, (MPEG 0043); 1 female (MPEG 0044) and 1 female (MPEG 0045), same data as holotype, L.S. Carvalho leg.; 1 female, same locality as holotype, N.F. Lo Man Hung leg., 14.XII.2007, (MZSP 28948); 2 females, Piauí, José de Freitas, Nazareth Farm, L.S. Carvalho leg., 06.X.2003, (MPEG 0047); 1 female, Piauí, José de Freitas, Nazareth Farm, G.A. Soares leg., 25.IX.2003, (MZSP 28949); 1 male, Piauí, Batalha, Paquetá Ambiental Park, F.N. Oliveira-Marques leg., 17.IV.2006, (MZSP 

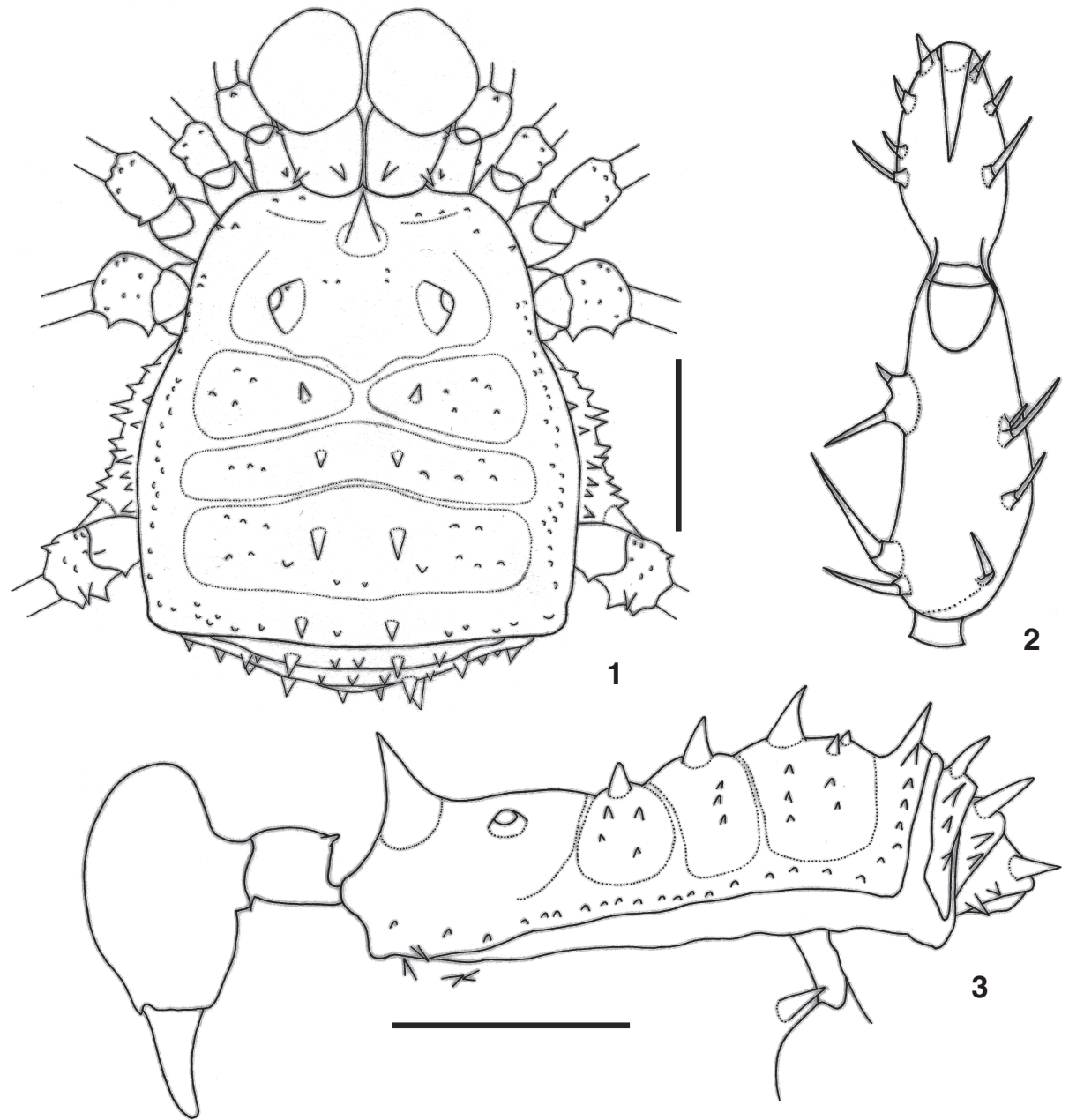

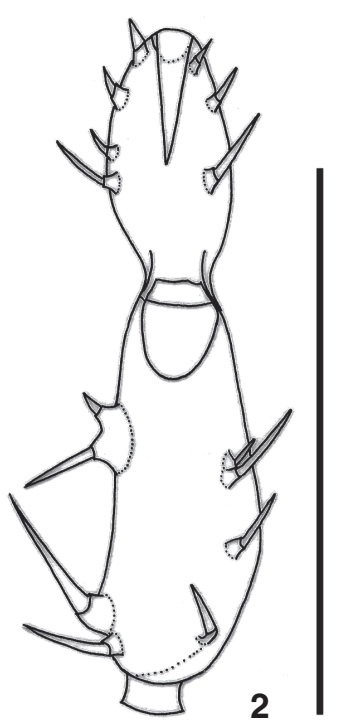

2

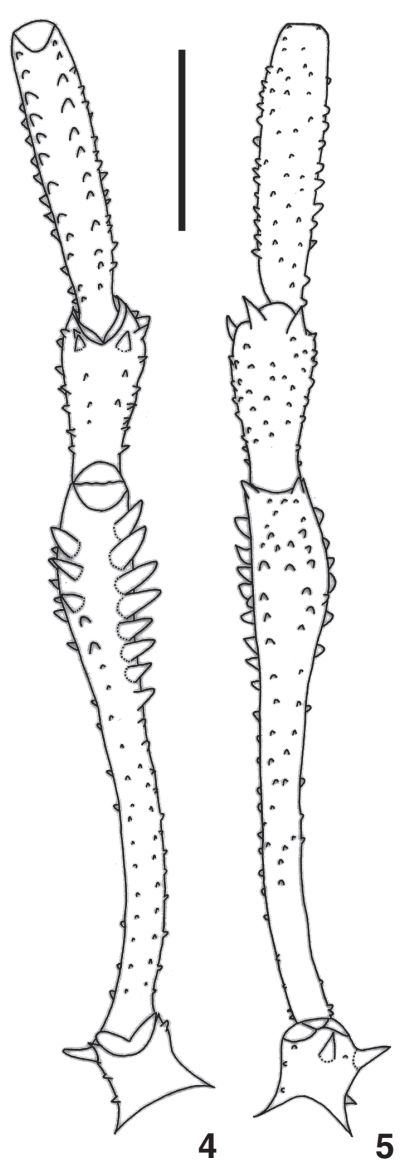

Figures 1-5. Sickesia tremembe, sp. nov. (1-2) Male holotype, habitus: (1) dorsal view; (2) right lateral view; (3) male holotype, right pedipalpal tibia and tarsus, ventral view; (4-5) male holotype, trochanter, femur, patella and tibia of the right leg IV: (4) ventral; (5) dorsal. Scale $=1 \mathrm{~mm}$.

28950); 2 females, Piauí, Batalha, Paquetá Ambiental Park, F.N. Oliveira-Marques leg., 08.IV.2006, (MPEG 0046); 2 males, Maranhão, Balsas $\left(07^{\circ} 28^{\prime} 44^{\prime \prime}\right.$, $\left.46^{\circ} 07^{\prime} 09^{\prime \prime} \mathrm{W}\right)$, H. Yamaguti, T. Porto \& M.B. da Silva leg., 04.VI.2008, (MZSP 29030).

Etymology. The specific name makes reference to the extinct indigenous tribe Tremembé, which lived in the State of Piauí and was known by its swimming abilities and courage of the warriors.

Diagnosis. Males of Sickesia tremembe resemble those of S. helmuti by the larger spines on areas I and II, but differs by the smooth claws on tarsi III-IV. S. tremembe differs from $S$. usta and $S$. helmuti by the clavate male femur IV and chelicerae segment I with a pair of large tubercles on retrolateral surface.

Description. Holotype male (MPEG 0042). Measurements. Dorsal scutum: length 1.46, width 1.48; prosoma: length 0.65 , width 1.20; interocular distance 1.05; chelicerae: II 0.57; III 0.35; pedipalpus 1.91; legs: I 5.70; II 9.90; III 7.40; IV 11.50. Dorsum. Anterior margin with two to three small tubercules on each side. Prosoma small tuberculate, with one forward spine near anterior margin. Lateral margins with tubercles from coxa II to posterior margin. Area I with five to six tubercles each side (one larger close to median groove); II with 10 tubercles (two larger); III with 11 tubercles (two larger on center of area). Posterior margin with one central with one larger each side and seven to three lateral tubercles. Free tergite I with two central tubercles, one larger each side and four lateral; II with one central with one larger each side and four lateral tubercles; III with two small central one larger each side and three lateral tubercles. Anal plate with one anterior and one posterior row of tubercles. Venter. Coxa I with six anterior tubercles, five median and four posterior; II with eight anterior tubercles, six median and for posterior; III with seven anterior tubercles, four median and six poste- 

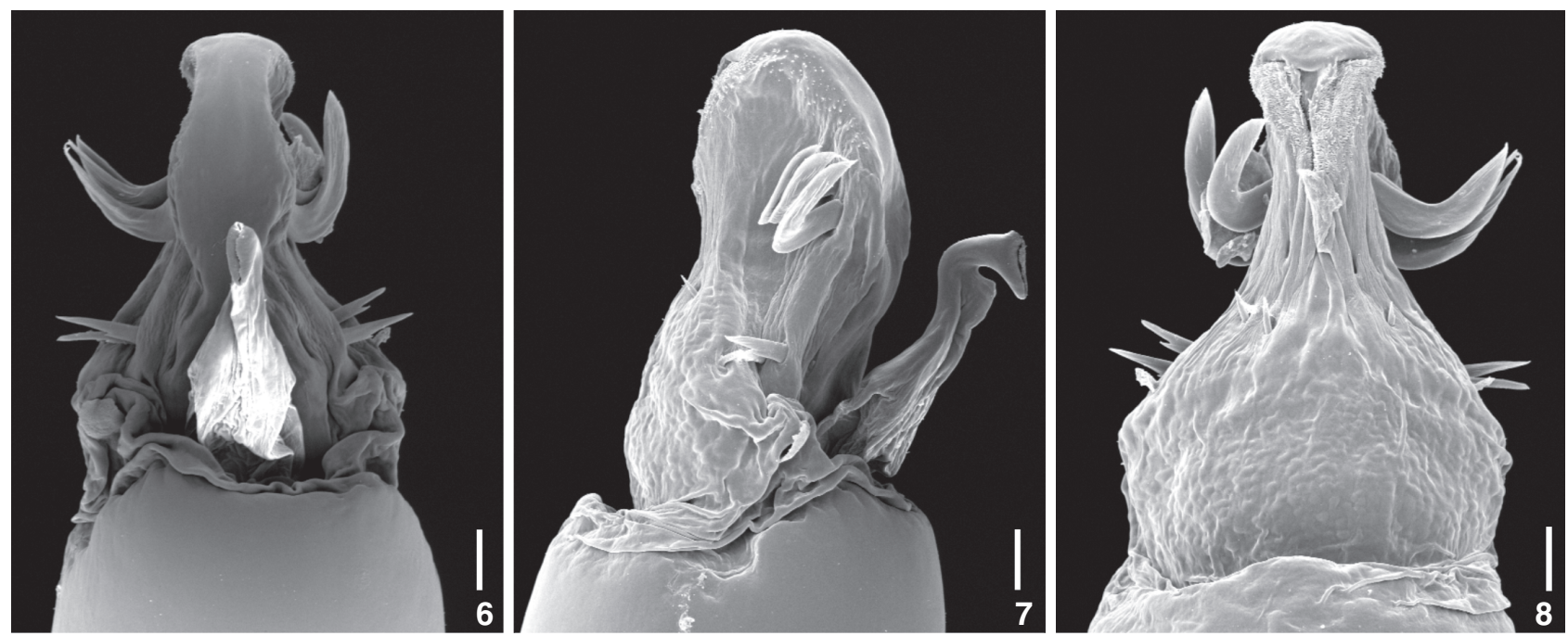

Figures 6-8. Sickesia tremembe sp. nov., holotype, apical portion of penis: (6) dorsal view; (7) right lateral view; (8) ventral view. Scale $=0.2 \mathrm{~mm}$.

rior; IV irregularly tuberculate. Stigmatic area irregularly tuberculate. Free sternites with one row of tubercles. Chelicerae. Swollen. Segment I with three tubercles on bulla; II with three small apical teeth and III with one large and one small tooth; with intercheliceral space. Pedipalpus. Coxa with one ventral and one dorsal tubercles. Trochanter with three ventral tubercles. Femur slightly curved, with four retrolateral and one prolateral median tubercles. Patella swollen at distal half, with one dorsal and one ventral tubercles. Tibia: flattened prolaterally, retrolateral iili, prolateral IIIi, not tuberculate. Tarsus: retrolateral Iii, prolateral Iiii, not tuberculate. Legs. Coxa I with one anterior tubercle and one posterior (larger); II with one anterior, one posterior fused apically with one of III; III with one posterior fused apically with one of IV; IV tuberculate with one lateral and one dorsoapical large tubercles, three retrolateral (basal larger). Trochanter III with two large retrolateral; IV with two retrolateral apical, two large dorsoapical. Femora III-IV with two ventral rows of tubercles, larger on distal half, one prolateral, one retrolateral, two dorsoapical (similar in size). Patella IV tuberculate, with one ventral, one prolateral, two retrolateral and one dorsal larger tubercles. Tibia IV with two ventral rows of wide tubercles. Claws parallels without teeth. Tarsal segmentation: 6, 9, 6, 7. Penis. Ventral plate narrow distally, lateral margins concave, distal margin straight. Coloration. Dark-brown. Margins of dorsal scute and free tergites almost black. Chelicerae reticulate in black.

Description. Female paratype (MPEG 0045). Measurements. Dorsal scutum: length 1.57, width 1.59; prosoma: length 0.65 , width 1.22 ; interocular distance 0.95 ; chelicerae: II 0.44 ; III 0.26; pedipalpus 1.96; legs: I 5.70; II 9.30; III 7.80; IV 11.70. Anterior margin with three tubercles each side. Area I with eight; II with four; III-IV with 17. Posterior margin with 21 tubercles. Free tergite I with 16 tubercles; II with three central with one large and five lateral each side; III with three central (median larger) with one large and two laterals, relatively small. Tarsal segmentation: $6,9,6,7$.

Distribution. Known only from central Piauí (Sete Cidades National Park, Nazareth Farm and Paquetá Ambiental Park) and Maranhão (Balsas).

Biological note. All specimens were collected in tropical semi-deciduous forests and were not found in others phytophysiognomies of the region. This formation is a dense and forested area, with canopy of $9 \mathrm{~m}$, which has a few individuals with $20 \mathrm{~m}$ height, abundant leaf litter on the ground, high abundance of lianas on sub-canopy, absence of epiphytes; and a flatland soil, usually with emerging rocks (OliveIra et al. 2007).

Variation. Males (three males). Dorsal scutum: length 1.391.54, width 1.41-1.57; prosoma: length 0.63-0.70, width 1.171.22; interocular distance 0.92-1.05; femur IV 1.41-1.57. Females (eight females).Dorsal scutum: length 1.41-1.74, width 1.43-1.70; prosoma: length 0.61-0.72, width 1.15-1.31; interocular distance 0.92-1.12; femur IV 2.34-2.71.

\section{Notes on the harvestman fauna from Piauí}

The inventory of arachnids over Piauí was carried out at three main sites: Sete Cidades National Park (between 2006 and 2007), Nazareth Farm (between 2003 and 2005) and Bonito Farm (between 2006 and 2007). The Sete Cidades National Park (04 $\left.06^{\prime} 25.76^{\prime \prime} \mathrm{S}, 041^{\circ} 40^{\prime} 39.32^{\prime \prime} \mathrm{W}\right)$ comprises well-preserved 6221 ha and it is covered by six phytophysiognomical types of Cerrado (savanna-like vegetation): grassland (medium tall grassland consisting mainly of bunch grasses occasionally/seasonally flooded); cerrado sensu strictu (evergreen broad-leaved sclerophyllous shrubland); cerrado rupestre (deciduous subdesert shrubland with succulents); cerradão (evergreen broad-leaved woodland); gallery 
forest (tropical ombrophilous alluvial occasionally flooded forest) and tropical semi-deciduous forest (Oliveira et al. 2007). The Nazareth Farm (04²7'38.37"S, 042³7'21.59"W, José de Freitas town) is in moderate state of preservation and covered by tropical semi-deciduous forest, cerrado sensu strictu and "mata dos cocais" (forests dominated by Arecaceae). It has a few water sources and is situated in the margins of the Bezerro Storage Dam. The Bonito Farm ( $05^{\circ} 12^{\prime} 42.0^{\prime \prime} \mathrm{S}, 041^{\circ} 42^{\prime} 13.4^{\prime \prime} \mathrm{W}$, Castelo do Piauí) is drier than others and located on an ecotonal area of the Biomes Cerrado and Caatinga, mostly covered by cerrado sensu strictu, cerrado rupestre and campo cerrado (opened Cerrado formation with grassland). The climate of all three localities is hot tropical semi-arid, with temperature ranging from $18^{\circ} \mathrm{C}$ and $38^{\circ} \mathrm{C}$ (average $25^{\circ} \mathrm{C}$ ) (ARAújo et al. 2006). Besides those localities, we occasionally sampled at other places, like some forest patches near the cities of Teresina (e.g., Sítio Ouro Verde, 04²5 '13.9"S, $42^{\circ} 47^{\prime} 27.1^{\prime \prime W}$ ), Uruçuí (e.g., União Farm, 07²41'41.3"S, $44^{\circ} 26^{\prime} 30.2^{\prime \prime} \mathrm{W}$ ), Oeiras (surroundings of the city, 06 $58^{\prime} 28.0^{\prime \prime} \mathrm{S}$, $042^{\circ} 06^{\prime} 31.0^{\prime \prime} \mathrm{W}$ ); and the Paquetá Ambiental Park (an area covered by well-preserved tropical semi-deciduous forest and gallery forest, at Batalha; $\left.03^{\circ} 58^{\prime} 82.8^{\prime \prime} \mathrm{S}, 042^{\circ} 05^{\prime} 65.9^{\prime \prime} \mathrm{W}\right)$. We also examined a few harvestman collected in Piauí by others researchers, in Teresina (Mocambinho Ambiental Park (0502'05.58"S 42 48' $\left.49.81^{\prime \prime} \mathrm{W}\right)$ and at the Uruçuí-Una Ecological Station (08 $50^{\circ} \mathrm{S}$, $44^{\circ} 10^{\prime} \mathrm{W}$, Uruçuí), which totalized 13 specimens.
The collecting methods and sampling intensity was not standardized over these localities; which hampered application of statistical comparisons between the data obtained. We sampled using six main techniques: beating tray (one hour samples); nocturnal hand searches (one hour samples); sweeping net (one hour samples); pit-fall traps for invertebrates $(500 \mathrm{ml}$ plastic buckets, sunk into the ground flush with the surface, filled with $300 \mathrm{ml}$ of $70-80 \%$ ethyl alcohol; five days samples); pit-fall traps with drift fences (blocks of four 601 plastic buckets, arranged like a "Y", with drift fences of $60 \mathrm{~cm}$ high; $24 \mathrm{~h}$ samples); and Winkler apparatus ( $1 \mathrm{~m}^{2}$ litter samples).

We examined 354 harvestmen (341 that we collected and 13 that were deposited in scientific collections) from different localities over the State, belonging to nine species and four families: Stygnidae, Stygnus polyacanthus (Mello-Leitão, 1923) (17 specimens), and Sickesia tremembe sp. nov. (11 specimens); Cosmetidae, Gryne pluriarcuata Mello-Leitão, 1936 (89 specimens), an undetermined species of Gryne Simon, 1879 (one specimen), and three undetermined species of Paecilaema C.L. Koch, 1839 (see table I for abundances); an undescribed species of Escadabiidae (possibly belonging to the genus Baculigerus H. Soares, 1979) (nine specimens); and also a single immature and undetermined specimen of Sclerosomatidae (Gagrellinae). These are the first records of those families from the State of Piauí. S. polyacanthus is widely distributed over the Northeast

Table I. Number of harvestman specimens collected in eleven localities in Piauí State, Brasil. (BF) Bonito Farm, Castelo do Piauí; (MAP) Mocambinho Ambiental Park, Teresina; (NF) Nazareth Farm, José de Freitas; (Oei) surrounding of the city of Oeiras; (PAP) Parquetá Ambiental Park, Batalha; (SCB) Sítio Carlos Brasil, Teresina; (SCNP) Sete Cidades National Park, Brasileira and Piracuruca; (sob) Sítio Ouro Verde, Teresina; (UF) União Farm, Uruçuí; (UFPI) campus of the Universidade Federal do Piauí, Teresina; (UUEE) Uruçuí-Una Ecological Station, Uruçuí.

\begin{tabular}{|c|c|c|c|c|c|c|c|c|c|c|c|c|}
\hline \multirow{2}{*}{ Taxa } & \multicolumn{11}{|c|}{ Localities } & \multirow{2}{*}{ Total } \\
\hline & $\mathrm{BF}$ & MAP & NF & Oei & PAP & SCB & SCNP & SOV & UF & UFPI & UUEE & \\
\hline \multicolumn{13}{|l|}{ Eupnoi } \\
\hline \multicolumn{13}{|l|}{ Sclerossomatidae } \\
\hline Undetermined species & & & & & & & & & 1 & & & 1 \\
\hline \multicolumn{13}{|l|}{ Laniatores } \\
\hline \multicolumn{13}{|l|}{ Cosmetidae } \\
\hline Gryne pluriarcuata & & 1 & 20 & & & 12 & 142 & 6 & & 2 & & 183 \\
\hline Gryne sp. 1 & & 1 & & & & & & & & & & 1 \\
\hline Paecilaema sp. 1 & 44 & & 20 & 1 & & 1 & 19 & 4 & & & & 89 \\
\hline Paecilaema sp. 2 & & & & & & & & & & & 10 & 10 \\
\hline Paecilaema sp. 3 & & & & & & & & & 32 & & & 32 \\
\hline \multicolumn{13}{|l|}{ Escadabiidae } \\
\hline cf. Baculigerus sp. 1 & 2 & & & & & 1 & 6 & & & & & 9 \\
\hline \multicolumn{13}{|l|}{ Stygnidae } \\
\hline Sickesia tremembe sp. nov. & & & 2 & & 3 & & 6 & & & & & 11 \\
\hline Stygnus polyacanthus & & & 2 & & & & 3 & 12 & & & 1 & 17 \\
\hline Total & 46 & 2 & 44 & 1 & 3 & 14 & 176 & 22 & 33 & 2 & 12 & 354 \\
\hline
\end{tabular}


Brazil, occurring from the State of Paraíba to Bahia (PINTO-DARосна 1997) and it was usually collected on the underside of fallen trunks or trunks on decomposition, including palm tree trunks. This species was collected at Sete Cidades National Park, Nazareth Farm and Sítio Ouro Verde (see Tab. I).

Gryne pluriarcuata was the most abundant species sampled and exhibits a gregarious behavior and can be found on leaf litter. This species was known only for its type locality (Tapera, Pernambuco), according to KuRY (2003); and now has its geographical distribution extended to Sete Cidades National Park, Nazareth Farm and surroundings of Teresina. The single specimen of Gryne sp. 1 was collected at the Mocambinho Ambiental Park (Teresina), on a pit-fall trap sample, with one specimen of G. pluriarcuata. The specimens of Paecilaema sp. 1 were collected at Sete Cidades National Park, Nazareth Farm, Bonito Farm and in the surroundings of the cities of Teresina and Oeiras (southern Piauí). The others species of Paecilaema were sampled exclusively at Uruçuí-Una Ecological Station (Paecilaema sp. 2), that is a huge protected area of 204,315 ha, on southern Piauí, in the domains of the Cerrado Biome; or at Uruçuí town (Paecilaema sp. 3). The representatives of this genus were seen wandering on the forest floor, above termite nests and tree trunks. The specimens of Escadabiidae were usually collected with pitfall traps, and a few specimens were captured, by nocturnal hand searches, inside termite nests at the Sete Cidades National Park and Bonito Farm. Sclerosomatidae was recorded only by a single specimen from the town of Uruçuí and it was collected using a pit-fall trap with drift fences in an exploratory expedition.

Although we have shown an abundance pattern of high dominance of two species (G. pluriarcuata and Paecilaema sp. 1) and low species richness (nine species), this fact can not be considered as the real diversity pattern of the harvestman fauna of Piauí, because the sampled areas are inexpressive compared to the hole State's dimensions and some regions remains unsampled, including those covered by the Caatinga Biome or the humid forested enclaves present on southern region. A few authors (Bragagnolo \& Pinto-DA-Rocha 2003, Pinto-DA-Rocha et al. 2005, PINTO-DA-RochA \& BONALDO 2006) showed that the harvestman richness in Cerrado is the lowest (4-7 species per site), when compared to forest biomes such as the Atlantic forest (12-64 species per site) or Amazon forest (21-28 species per site), which creates an expectative of some new findings with an increase of the harvestman sampling at Piauí State. Besides, the low richness of harvestmen species from Piauí appears to be restricted to the rare environmental humid conditions. Therefore, an intensive collecting effort at the remaining unsampled regions is highly required for a robust knowledge of this fauna.

\section{ACKNOWLEDGEMENTS}

We thank to G.A. Soares, F.M. Oliveira-Neto, E.B.O. Marques, D.F. Candiani and N.F. Lo Man Hung for their help with harvestman sampling; M.P.D. Santos for his help on field expeditions and logistics; and J.Q. Sousa and L.S. Fontes for loan of two specimens collected at Teresina. We also thank A. P. González for Escadabiidae identification; A. L. Tourinho and two anonymous referees for comments on the manuscript. LSC was M.Sc. student of the Programa de Pós-Graduação em Zoologia, Museu Paraense Emílio Goeldi and Universidade Federal do Pará. This work is part of Programa de Pesquisas Ecológicas de Longa Duração (Sítio 10, Sítio ECOCEM, MCT/CNPq \#521131/20014). This work has been supported by CNPq (RPR, PQ grant \#476523/2003-6; LSC, M.Sc. grant \#131207/2006-1) and FAPESP (RPR grant \#2008/06604-7).

\section{LITERATURE CITED}

Araújo, J.L.L.; I.M.M.F. Lima; I.G. Abreu; E.M.C.G. Rebêlo; M.C.S.A. Nunes \& M.M.B. ARAújo. 2006. Atlas escolar Piauí: geo-histórico e cultural. João Pessoa, Editora Grafset, 202p.

Bragagnolo, C. \& R. Pinto-Da-Rocha. 2003. Diversidade de opiliões do Parque Nacional da Serra dos Órgãos, Rio de Janeiro, Brasil (Arachnida: Opiliones). Biota Neotropica 3 (1): 1-20.

Carvalho, L S.; M.P.D. Santos \& S.C. Dias. 2007a. Escorpionismo na zona rural de Teresina, Estado do Piauí: relato de casos de envenenamento. Revista da Sociedade Brasileira de Medicina Tropical 40 (4): 1-1.

Carvalho, L.S.; A.B. Bonaldo \& A.D. Brescovit. 2007b. The first record of the family Cithaeronidae (Araneae, Gnaphosoidea) to the new world. Revista Brasileira de Zoologia 24 (2): 512-514.

Castro, A.A.J.F.; N.M.C.F. Castro; J.M. Costa; R.R.S. Farias; M.R.A. Mendes; R.S. Albino; J.S. Barros; M.E.A. Oliveira.2007. Cerrados Marginais do Nordeste e Ecótonos Associados. Revista Brasileira de Biociências 5: 273-275.

Ducke, A. \& G.A. Black. 1953. Phytogeographical notes on the Brazilian Amazon. Anais da Academia Brasileira de Ciências 25: 1-46.

GuADANUCCI, J.P.L. 2007. Revision of the Neotropical spider genus Oligoxystre Vellard, 1924 (Theraphosidae, Ischnocolinae). Zootaxa 1555: 1-20.

GuadanucCI, J.P.L.; S.M. Lucas; R.P. IndicatTI \& F. U. Yamamoto. 2007. Description of Guyruita gen.n. and two new species (Ischnocolinae, Theraphosidae). Revista Brasileira de Zoologia 24: 991-996.

Hara, M.R. \& Pinto-Da-Rocha, R. 2008. A new species and new distribution records of Pickeliana (Opiliones: Laniatores: Stygnidae). Revista brasileira de Zoologia 25 (3): 515-522.

KurY, A.B. 2003. Annotated catalogue of the Laniatores of the New World (Arachnida, Opiliones). Revista Ibérica de Aracnologia, vol. especial monográfico 1: 1-337.

KurY, A.B. \& R. PinTo-DA-RochA. 2008. First record of Stygnidae for the state of Espírito Santo and description of a new Protimesius (Arachnida: Opiliones: Laniatores). Revista Brasileira de Zoologia 25: 319-322.

Lourenço, W.R. 2002. Scorpions of Brazil. Paris, Les Editions de L'IF, 320p. 
Lourenço, W.R.; M.M.B.G. Jesus-Junior \& F. Limeira-De-Oliveira. 2006. New species of Tityus C. L. Koch, 1836 (Scorpiones, Buthidae) from the State of Maranhão in Brazil. Boletín Sociedad Entomológica Aragonesa 38 (1): 117-120.

Lucas, S.; A. Cirelli; I. Knysak \& L.F. Zveibil. 1979. Aracnídeos coletados no Piauí durante a realização do projeto Rondon XXII. Memórias do Instituto Butantan 42: 127-138.

Oliveira, M.E.A.; F.R. Martins; A.A.J.F. Castro \& J.R. SAntos. 2007. Classes de cobertura vegetal do Parque Nacional de Sete Cidades (transição campo-floresta) utilizando imagens TM/Landsat, NE do Brasil, p. 1775-1783. In: Anais XIII Simpósio Brasileiro de Sensoriamento Remoto. Florianópolis, INPE, 7103p.

PINTO-DA-Rocha, R. 1997. Systematic review of the Neotropical family Stygnidae (Opiliones, Laniatores, Gonyleptoidea). Arquivos de Zoologia 33 (4): 163-342.

PinTo-DA-Rocha, R. \& A.B. Bonaldo. 2006. A structured inventory of harvestmen (Arachnida, Opiliones) at Juruti River plateau, State of Pará, Brazil. Revista Ibérica de Aracnología 13: 155-162.

Pinto-da-Rocha, R.; M.B. Silva \& C. Bragagnolo. 2005. Faunistic similarity and historic biogeography of the harvestmen of southern and southeastern Atlantic Rain Forest of Brazil. Journal of Arachnology 33 (2): 290-299.

PinTo-DA-Rocha, R. 2007. Stygnidae Simon, 1879, p. 226-229. In: R. PinTo-DA-Rocha; G. MAchado \& G.Giribet (Eds). Harvestmen: the biology of Opiliones. Cambridge, Harvard University Press, 597p.

Rizzını, C.T. 1963. Nota prévia sobre a divisão fitogeográfica (florístico-sociológica) do Brasil. Revista Brasileira de Geografia 25: 3-65.

Ruiz, G.R.S. \& A. D. BRescovit. 2006. Description of the male of Aillutticus rotundus Galiano and five new species of Aillutticus Galiano from Brazil (Araneae, Salticidae, Sitticinae). Revista Brasileira de Zoologia 23 (2): 529-536.

Santos, A.J. \& A.D. Brescovit. 2001. A revision of the South American spider genus Aglaoctenus Tullgren, 1905 (Araneae, Lycosidae, Sosippinae). Andrias 15: 75-90.

Villarreal-Manzanilla, O. \& R. Pinto-da-Rocha. 2006. Five new species of Protimesius from Brazil (Opiliones: Stygnidae). Zootaxa 1325: 219-233.

Submitted: 08.VIII.2008; Accepted: 15.IV.2009.

Editorial responsibility: Antonio Domingos Brescovit 